\title{
Penyusunan soal tes bermuatan lower dan higher-order thinking skills pada guru SMP
}

\section{Ega Gradini}

Institut Agama Islam Negeri Takengon, Aceh, Indonesia, email: ega.gradini@gmail.com

\section{Info Artikel}

Diajukan: 08 Feb 2021

Diterima: 01 Jul 2021

Diterbitkan: 09 Jul 2021

Keywords:

teacher competence; LOTS; HOTS; test; assessment

Kata Kunci:

kompetensi guru; LOTS; HOTS; soal tes; asessmen

\section{Lisensi:}

cc-by-sa

\begin{abstract}
Training for Junior High School's teacher on constructing LOTS and HOTS questions aims to (1)improve teacher competence on designing lower and higher-order thinking skills assessment; and (2)provide teachers with an understanding of the formulation of successful test questions and the evaluation criteria set by the Ministry of Education and Culture. The training was given to 31 teachers of SMP IT Cendikia Takengon in stages; (1) pre-training observations; (2) tutorial and practice; (3) assistance; and (4) evaluation. The training conducted on August 14 to October 20, 2020. Based on the results of evaluation and reflection, it is found that; (1) teachers were able to write questions, both multiple-choice and essays questions, following the principles of writing questions; (2) teachers were able to understand and distinguish between cognitive levels (levels 1,2 and 3) and cognitive dimension (C1, C2, C3, C4, C5, and C6); (4) teachers generally have been able to compile HOTS questions although some teachers still have difficulty designing HOTS questions; (5) Teachers understand that HOTS questions are not difficult questions, but level 3 questions that involve reasoning; and (6) teachers understand that structured and non-structured test if properly designed have the potential to measure both lower and higher-order thinking skills.
\end{abstract}

\section{Abstrak}

Pelatihan penyusunan soal bermuatan LOTS dan HOTS pada guru bertujuan untuk; (1) meningkatkan kompetensi guru dalam merancang tes yang mengukur kemampuan berpikir tingkat rendah dan tingkat tinggi; dan (2) memberikan pemahaman kepada guru tentang perumusan soal tes yang baik dan sesuai standar penilaian. Pelatihan diberikan kepada 31 orang guru SMP-IT Cendikia Takengon dengan tahapan; (1) Observasi awal; (2) pelatihan (tutorial dan praktik); (3) pendampingan; dan (4) evaluasi. Seluruh tahapan kegiatan berlangsung pada 14 Agustus - 20 Oktober 2020. Berdasarkan hasil evaluasi dan refleksi, diperoleh bahwa; (1) guru-guru telah mampu menuliskan soal sesuai dengan kaidah penulisan soal, baik soal pilihan ganda maupun uraian; (2) guru-guru telah mampu memahami dan membedakan antara level kognitif (Level 1,2, dan 3) dan dimensi kognitif (C1, C2, C3, C4, C5, dan C6); (3) guru-guru telah mampu memahami dan membedakan soal LOTS dan HOTS; (4) umumnya guru telah mampu menyusun soal HOTS meski terdapat beberapa guru yang masih kesulitan merancang soal HOTS; (5) guru telah mengetahui bahwa soal HOTS bukanlah soal sulit, melainkan soal level 3 yang melibatkan penalaran (reasoning); dan (6) guru-guru memahami bahwa soal tes terstruktur dan tidak terstruktur bila dirancang dengan baik potensial untuk mengukur baik kemampuan berpikir tingkat rendah maupun tingkat tinggi. 


\section{PENDAHULUAN}

Penilaian hasil belajar siswa masih menjadi tantangan bagi sebagian besar guru. Merancang alat asesmen yang tepat untuk mengukur pemahaman dan hasil belajar siswa adalah unsur terpenting yang harus dikuasai guru dalam penilaian. Tantangan ini menjadi semakin berat karena instrument penilaian yang dirancang bertujuan tidak hanya memonitor perkembangan siswa. Instrumen penilaian yang baik haruslah dapat mengukur ketercapaian kompetensi siswa sesuai dengan tuntutan kurikulum yang kian berat, mendiagnosa kelemahan belajar setiap siswa, dan menentukan keefektifan pembelajaran yang telah dilaksanakan.

Hasil survei terhadap guru-guru SMP Islam Terpadu Cendikia Takengon mengungkapkan bahwa guru masih kesulitan mendesain tes hasil belajar yang baik. Problematika yang dihadapi para guru antara lain; (1) Menyusun soal tes yang komprehensif, (2) merumuskan soal sesuai dengan level kognitif, (3) membedakan soal LOTS dan HOTS, dan (4) memberikan skor yang tepat. Temuan ini diperkuat oleh hasil wawancara dengan Wakil Kepala Bidang Kurikulum dan Pengajaran yang menyatakan bahwa kualitas soal tes yang disusun guru masih belum memadai. Diperlukan peninjauan dan revisi pada setiap periode penilaian, baik pada Penilaian Tengah Semester (PTS) maupun Penilaian Akhir Semester (PAS). Selain faktor-faktor diatas, kontruksi soal tes juga masih menjadi problema tersendiri. Sebagian besar guru mengalami kendala dalam mengkonstruksi tes berbentuk pilihan ganda dan uraian, baik yang bersifat substansi maupun teknis.

Penilaian Tengah Semester (PTS) dan Penilaian Akhir Semester (PAS) di SMP IT Cendikia Takengon dilakukan dengan tes tertulis dan ujian praktik bagi mata pelajaran tertentu. Oleh karena itu, kualitas tes tertulis menjadi prioritas dalam pengembangan kompetensi guru SMP IT Cendikia Takengon. Di SMP IT Cendikia Takengon, tes tertulis terdiri atas tes dengan pilihan jawaban (non-constructed response test) dan tes tanpa pilihan jawaban (constructed response test). Kemampuan guru dalam menyusun soal tes terstruktur dan tidak terstruktur untuk mengukur kemampuan berpikir tingkat rendah dan tingkat tinggi belum memadai. Oleh karena itu, perlu peningkatan kompetensi guru dalam Menyusun soal tes melalui pelatihan penyusunan soal tes yang dapat mengukur kemampuan berpikir tingkat rendah dan tingkat tinggi dengan efektif sehingga data hasil belajar siswa yang diperoleh valid.

Pelatihan ini bertujuan untuk meningkatkan kompetensi guru dalam merancang tes yang mengukur kemampuan berpikir tingkat rendah dan tingkat tinggi. Lebih lanjut, pelatihan ini juga memberikan pemahaman kepada guru tentang perumusan soal tes yang baik dan sesuai standar penilaian yang diatur oleh Kementerian Pendidikan dan Kebudayaan melalui Pusat Penilaian Pendidikan.

Terdapat kaitan erat antara kualitas pengajaran dan penilaian. Phelps (2012) berteori bahwa penilaian yang diberikan guru mempengaruhi pencapaian akademis siswa dan dapat mempengaruhi motivasi, dan efikasi diri siswa. McMillan et al. (2013) menemukan bahwa terdapat hubungan antara praktik penilaian formatif dan prestasi belajar siswa, dimana ukuran efek 
median dari korelasi tersebut berada pada kisaran $0,40-0,70$. Wiliam et al (2004) bahkan menyatakan secara spesifik tentang dampak positif terhadap prestasi siswa ketika guru mendesain dan mengembangkan sendiri assessmen/penilaian. Data hasil penelitiannya mengindikasikan bahwa mengajar dengan baik dapat sejalan dengan menilai yang baik pula. Popham (2003) meyakini tes yang baik mewujudkan pengajaran yang lebih baik. Dalam penelitiannya, Popham (2003) menemukan bahwa guru yang merancang tesnya dengan baik lebih mampu memperbaiki dan meningkatkan kompetensinya dalam mengajar. Meski terlihat sederhana, dari perspektif guru, sulit untuk mencari tahu mengapa tes yang berkualitas menghasilkan kualitas pengajaran yang lebih tinggi, terutama karena hasil tes saat ini memiliki sedikit kegunaan di kelas. Faktanya, banyak guru menemukan bahwa manfaat instruksional yang diperoleh dari tes hanya terbatas pada nilai hasil belajar siswa yang seringkali bahkan tidak menunjukkan nilai sebenarnya dari pemahaman kognitif mereka. Jarang sekali guru menemukan bahwa kinerja siswa pada tes dapat membantu guru mendiagnosis kekuatan dan kelemahan siswa tersebut. Jarang sekali guru menemukan bahwa kinerja tes siswa memberi mereka gagasan yang lebih baik tentang apa yang perlu mereka lakukan secara instruksional untuk membantu siswa tersebut mencapai hasil yang lebih baik. Para guru mengeluhkan adanya tekanan dan tanggung jawab moral untuk memberikan nilai yang baik dan memuaskan kepada siswa.

Membahas higher-order thinking skills tidak dapat dipisahkan dari taksonomi Bloom. Bloom et al., (1956) mengusulkan taksonomi kognitif yang konsisten dengan pemikiran kritis dan hierarki pembelajaran pendidikan. Taksonomi Bloom yang direvisi diperkenalkan oleh Anderson et al., (2001) telah memasukkan prototipe yang berpusat pada peserta didik ke dalam taksonomi asli, yang bertujuan untuk meningkatkan pemahaman peserta didik. Dimensi proses kognitif mempertahankan enam kategori tetapi dengan perubahan substansial. Pada dasarnya, enam fitur utama Bloom diubah dari kata benda ke bentuk kata kerja untuk menandakan pentingnya tindakan pelajar. Selain itu, pengetahuan dari taksonomi lama diganti namanya mengingat dalam taksonomi yang direvisi. Namun, application/applying, analysis/applying, dan evaluation/evaluating kategori taksonomi Bloom tetap dipertahankan. Akhirnya, kategori sintesis diberi judul untuk menciptakan, dan urutan synthesis/creating dan evaluation/evaluating dipertukarkan dalam taksonomi yang direvisi. Berbeda dengan taksonomi asli, taksonomi yang direvisi Anderson memungkinkan kategori untuk tumpang tindih satu sama lain (Wilson, 2016).

Tabel 1. Keterampilan berpikir dalam Taksonomi Berpikir Bloom

\begin{tabular}{lc}
\hline \multicolumn{1}{c}{ Taksonomi Bloom } & Level \\
\hline C6 & \\
$\begin{array}{l}\text { Kemampuan memadukan unsur-unsur menjadi sesuatu bentuk baru yang } \\
\text { utuh dan luas, atau membuat sesuatu yang orisinil }\end{array}$ & $\begin{array}{l}\text { Higher Order } \\
\text { C5 }\end{array}$ \\
$\begin{array}{l}\text { Kemampuan menetapkan derajat sesuatu berdasarkan norma, kriteria } \\
\text { atau patokan tertentu }\end{array}$ & $\begin{array}{c}\text { (HOTS) } \\
\text { (HOTs }\end{array}$ \\
\end{tabular}


Taksonomi Bloom

Level

C4

Kemampuan memisahkan konsep ke dalam beberapa komponen dan menghubungkan satu sama lain untuk memperoleh pemahaman atas konsep secara utuh

\section{C3}

Kemampuan melakukan sesuatu dan mengaplikasikan konsep dalam situasi tertentu

C2

Kemampuan memahami instruksi dan menegaskan ide atau konsep yang telah diajarkan

C1

Lower Order

Thinking Skills

(LOTS)

Kemampuan menyebutkan kembali informasi yang tersimpan dalam ingatan

Berdasarkan taksonomi Bloom, keterampilan berpikir manusia dapat diklasifikasikan ke dalam dua kelompok besar yaitu (1) keterampilan berpikir tingkat rendah (Lower-Order Thinking Skills-LOTS), dan (2) keterampilan berpikir tingkat tinggi (Higher-Order Thinking Skills). LOTS adalah tiga dimensi pertama dari taksonomi Bloom, yaitu mengingat, memahami, dan menerapkan. Sementara HOTS adalah tiga dimensi terakhir dari yaitu menganalisis, mengevaluasi, dan menciptakan (Stanley \& Moore, 2013). Dengan kata lain, HOTS adalah bagian tertinggi dalam taksonomi domain kognitif Bloom (Gradini, 2019).

Newmann (1991) mengemukakan perbedaan antara pemikiran tingkat rendah dan tinggi. Newman menyatakan bahwa pemikiran tingkat rendah hanya menuntut aplikasi rutin atau mekanis dari informasi yang diperoleh sebelumnya, seperti daftar informasi yang sebelumnya dihafal dan memasukkan angka ke dalam formula yang dipelajari sebelumnya. Sebaliknya pemikiran tingkat tinggi menantang siswa untuk menafsirkan, menganalisis, atau memanipulasi informasi. Berpikir tingkat tinggi terjadi ketika siswa saling berhubungan, mengatur ulang dan memperluas pengetahuan yang tersimpan dalam ingatan mereka (Lewis et al., 2009). Berikut ini disajikan ragam makna/ definisi HOTS menurut para ahli.

Tabel 2. Ragam Makna Kemampuan Berpikir Tingkat Tinggi (Gradini et al., 2018)

\begin{tabular}{|c|c|c|}
\hline Sumber & Tahun & Definisi \\
\hline King et al. & 1998 & $\begin{array}{l}\text { "mencakup pemikiran kritis, logis, reflektif, metakognitif, dan } \\
\text { kreatif. Diaktifkan ketika individu menghadapi masalah yang tidak } \\
\text { dikenal, ketidakpastian, pertanyaan, atau dilema". }\end{array}$ \\
\hline NCTM & 2000 & "Menyelesaikan masalah/soal rutin" \\
\hline $\begin{array}{l}\text { Anderson and } \\
\text { Krathwohl }\end{array}$ & 2001 & Proses-analisis, evaluasi, dan kreasi \\
\hline $\begin{array}{l}\text { Lopez and } \\
\text { Whittington }\end{array}$ & 2001 & $\begin{array}{l}\text { "terjadi ketika seseorang mengambil informasi baru dan informasi } \\
\text { yang disimpan dalam memori dan saling berhubungan dan/atau } \\
\text { mengatur ulang dan memperluas informasi ini untuk mencapai } \\
\text { tujuan atau menemukan jawaban yang mungkin dalam situasi } \\
\text { yang membingungkan". }\end{array}$ \\
\hline Weiss, E. & 2003 & Kolaboratif, otentik, Tidak Terstruktur, Masalah yang menantang \\
\hline
\end{tabular}




\begin{tabular}{|c|c|c|}
\hline Sumber & Tahun & Definisi \\
\hline Miri et al. & 2007 & $\begin{array}{l}\text { "... Strategi-pengaturan meta-tujuan; sedangkan pemikiran kritis, } \\
\text { sistemik, dan kreatif adalah taktik-kegiatan yang diperlukan untuk } \\
\text { mencapai tujuan yang dicanangkan." }\end{array}$ \\
\hline Rajendran, N. & 2008 & $\begin{array}{l}\text { Penggunaan pikiran yang diperluas untuk menghadapi tantangan } \\
\text { baru. }\end{array}$ \\
\hline Thompson, $\mathrm{T}$. & 2008 & "Berpikir-Non Algoritmik" \\
\hline $\begin{array}{l}\text { Thomas, A. and } \\
\text { Thorne, G. }\end{array}$ & 2010 & $\begin{array}{l}\text { "... (Itu) membutuhkan pemikiran ke tingkat yang lebih tinggi } \\
\text { daripada hanya menyatakan kembali fakta. (Itu) mengharuskan } \\
\text { kita melakukan sesuatu dengan fakta. Kita harus memahami } \\
\text { mereka, menghubungkan mereka satu sama lain, } \\
\text { mengkategorikan mereka, memanipulasinya, menyatukannya } \\
\text { dengan cara baru atau baru, dan menerapkannya ketika kita } \\
\text { mencari solusi baru untuk masalah baru”. }\end{array}$ \\
\hline Kruger, $\mathrm{K}$. & 2013 & $\begin{array}{l}\text { melibatkan "pembentukan konsep, pemikiran kritis, } \\
\text { kreativitas/brainstorming, penyelesaian masalah, representasi } \\
\text { mental, penggunaan aturan, penalaran, dan pemikiran logis." }\end{array}$ \\
\hline
\end{tabular}

Untuk mengoptimalkan pembelajaran berorientasi HOTS, guru sebaiknya mempersiapkan penilaian HOTS yang berbasis refleksi diri siswa. Oleh karena itu, Suyitno (2015) menyarankan agar para guru dilatih untuk membuat soal-soal yang meningkatkan kemampuan literasi siswa, yakni soalsoal yang dalam pengerjaannya bersifat; (1) tidak rutin; (2) bersifat pemecahan masalah; (3) memerlukan daya penalaran yang tinggi (higher-order thinking skills) dari siswa; (4) solusi soalnya memerlukan dua rumus atau lebih (untuk mata pelajaran matematika), (5) memuat tafsiran pemanfaatan konsep dalam berbagai konteks; dan (6) mampu menumbuhkan keterampilan berpikir kreatif siswa. Hal ini sesuai dengan tuntutan kompetensi guru, dimana guru sebagai agen pembelajaran tidak hanya membuat rencana dan melakukan proses pembelajaran, tetapi juga mengevaluasi dengan melakukan penilaian terhadap seluruh proses pembelajaran (Dewi \& Handayani, 2020). Selain itu, kegiatan ini penting untuk dilakukan mengingat meskipun HOTS telah menjadi tuntutan Kurikulum 2013, beberapa penelitian menunjukkan bahwa guru tidak terbiasa menggunakan soal HOTS dalam pembelajaran (Hidayati, 2017; Lestari et al., 2016; Miarsyah \& Ristanto, 2019; Wicaksono \& Jumanto, 2019).

\section{METODE PELAKSANAAN}

Pelaksanaan kegiatan pengabdian dilakukan dalam beberapa tahap dimulai pada bulan Agustus sampai Oktober 2020. Mitra dalam pengabdian ini adalah SMP IT Cendikia Takengon yang bertempat di Jalan Pertamina Nomor 23, Desa Lemah Burbana, Kecamatan Bebesen, Kabupaten Aceh Tengah.

Pelatihan penyusunan soal tes bermuatan lower dan higher-order thinking skills pada guru SMP IT Cendikia Takengon dilakukan dengan 3 tahapan, yaitu:

1. Observasi Awal

Pada tahap ini, pengabdi melakukan survei kepada guru SMP IT Cendikia Takengon untuk mengetahui problematika penyusunan soal tes bermuatan LOTS dan HOTS. Pengabdi juga melakukan wawancara dengan Wakil 
Kepala Bidang Kurikulum dan Pengajaran untuk menentukan kegiatan pelatihan dan prioritas pelatihan. Kegiatan ini dilaksanakan pada minggu ke-3 dan ke-4 Agustus 2020.

2. Pelatihan

Tahap ini terdiri atas tutorial dan praktik. Pengabdi memberikan tutorial penyusunan soal pada guru-guru SMP IT Cendikia Takengon. Kegiatan ini dilaksanakan pada minggu ke-1 bulan September 2020 dengan melibatkan 31 guru SMP IT Cendikia. Materi yang disampaikan pada tahap tutorial meliputi; (1) konsep soal LOTS dan HOTS; (2) penyusunan soal sesuai level kognitif; (3) konstruksi soal Pilihan Ganda (PG) yang baik; (4) konstruksi soal uraian yang baik.

Setelah tahap tutorial selesai, kegiatan dilanjutkan dengan praktik. Pengabdi meminta guru-guru untuk membentuk kelompok sesuai mata pelajaran dan menyusun soal tes bermuatan LOTS dan HOTS. Pengabdi lalu meminta setiap kelompok guru mempresentasikan hasil praktik mereka.

3. Pendampingan/Penerapan

Pada tahap ini, pengabdi melakukan pendampingan pada beberapa guru dalam menyusun soal tes untuk Penilaian Akhir Sekolah (PAS). Karena keterbatasan waktu dan tenaga, pengabdi hanya mendampingi 1 orang guru untuk setiap mata pelajaran.

4. Evaluasi

Pada tahap ini evaluasi dilakukan terhadap kualitas soal tes yang disusun oleh guru. Aspek yang dievaluasi meliputi; (1) butir Soal Tes, (2) kejelasan instruksi, (3) relevansi soal sesuai kemampuan berpikir tingkat rendah dan tingkat tinggi, (4) alokasi waktu untuk setiap bagian tes; (5) relevansi isi tes dengan pengalaman belajar siswa, (6) rubrik jawaban/ kunci jawaban, (7) pedoman penskoran.

\section{HASIL DAN PEMBAHASAN}

Kegiatan pengabdian kepada masyarakat ini berlangsung dengan baik dan lancar. Kegiatan dilaksanakan dengan tetap mengikuti protokol kesehatan dalam masa pandemi Covid-19. Kegiatan dilaksanakan di aula SMP IT Cendikia Takengon dengan melibatkan 31 orang guru. Peserta sangat antusias dan proaktif dalam baik saat kegiatan tutorial, praktik, pendampingan, hingga evaluasi.

Kegiatan tutorial dilaksanakan pada 2 September 2020. Kegiatan diawali dengan pembukaan oleh Wakil Kepala Bidang Kurikulum, Henny Mutia, S.Pd., yang menyampaikan bahwa tujuan dilaksanakannya pelatihan ini adalah agar para guru SMP IT Cendikia Takengon dapat menyusun soal bermuatan keterampilan berpikir tingkat rendah dan tingkat tinggi. Selain itu, agar siswa/i SMP IT Cendikia Takengon terbiasa menyelesaikan soal LOTS dan HOTS sesuai dengan tuntutan Kurikulum 2013 melalui Asessmen Kriteria Minimum (AKM) yang berlangsung pada 2021. Wakil kepala Bidang Kurikulum juga menyampaikan bahwa soal yang disusun dalam pelatihan ini akan digunakan 
pada Penilaian Tengah Semester (PTS) dan Penilaian Akhir Semester (PAS) di SMP IT Cendikia Takengon.

Sebelum menyampaikan materi, pengabdi mendistribusikan kuesioner sederhana untuk mengukur persepsi guru terhadap soal LOTS dan HOTS. Kuesioner berisikan 6 pernyataan sederhana yang mendeskripsikan pengalaman dan pandangan guru tentang HOTS dengan 2 pilihan jawaban; "ya" dan "tidak", sebagaimana disajikan pada tabel 3.

Tabel 3. Kuesioner pra-pendampingan

\begin{tabular}{|c|c|c|c|}
\hline & Pernyataan & Ya & Tidak \\
\hline P1 & Soal HOTS adalah soal yang sulit. & & \\
\hline P2 & $\begin{array}{l}\text { Level soal HOTS berada pada level C4, C5, dan C6 pada } \\
\text { taksonomi Bloom }\end{array}$ & & \\
\hline P3 & $\begin{array}{l}\text { HOTS adalah keterampilan berpikir tingkat tinggi sementara } \\
\text { LOTS adalah keterampilan berpikir tingkat rendah. }\end{array}$ & & \\
\hline P4 & $\begin{array}{l}\text { Jika soal HOTS dapat dikerjakan oleh mayoritas siswa, maka } \\
\text { soal tersebut bukanlah soal HOTS. }\end{array}$ & & \\
\hline P5 & $\begin{array}{l}\text { Soal HOTS adalah soal uraian berbentuk cerita, bukan pilihan } \\
\text { berganda. }\end{array}$ & & \\
\hline P6 & $\begin{array}{l}\text { Guru sebaiknya tidak mendesain soal HOTS sendiri karena } \\
\text { susah dalam membuatnya }\end{array}$ & & \\
\hline
\end{tabular}

Hasil kuesioner disajikan pada diagram berikut.

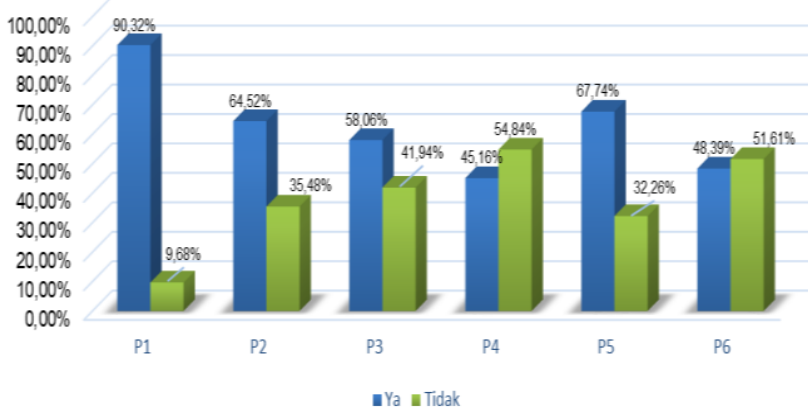

Gambar 1. Hasil kuesioner pra-pendampingan

Kuesioner yang disebarkan pada 31 guru dampingan memberikan hasil sebagai berikut. $90,32 \%$ guru meyakini soal HOTS adalah soal yang sulit. Hal ini dikarenakan $64,52 \%$ guru memahami bahwa level soal HOTS berada pada level C4, C5, dan $\mathrm{C} 6$ pada taksonomi Bloom dan level ini merupakan level yang sulit. 58,06\% guru telah memahami bahwa HOTS adalah keterampilan berpikir tingkat tinggi sementara LOTS adalah keterampilan berpikir tingkat rendah. Sementara itu, $45,16 \%$ guru menyatakan jika soal HOTS dapat dikerjakan oleh mayoritas siswa, maka soal tersebut bukanlah soal HOTS. Lebih lanjut, $67,74 \%$ guru memahami soal HOTS adalah soal uraian berbentuk cerita, bukan pilihan berganda. Lebih lanjut, 48,39\% guru berpendapat bahwa guru sebaiknya tidak 
mendesain soal HOTS sendiri karena susah dalam membuatnya, sementara $51,61 \%$ guru berpendapat sebaliknya.

Kegiatan berikutnya adalah penyampaian materi oleh pengabdi, yakni Ega Gradini, M.Sc. Materi yang disampaikan adalah urgensi penyusunan soal tes yang baik, pengertian dan karakteristik soal LOTS-HOTS, dan contohcontoh soal bermuatan LOTS-HOTS. Antusiasme peserta telah terlihat pada sesi ini, dimana banyak pertanyaan diajukan oleh peserta kepada pemateri. Sesi tanya jawab ini sekaligus menjadi wadah penyamaan persepsi dan meluruskan mispersepsi guru yang tertuang pada kuesioner sederhana yang didistribusikan di awal kegiatan.

Penyajian materi selanjutnya adalah penyusunan soal LOTS dan HOTS berdasarkan tingkatan kognitif siswa. Pengabdi menekankan bahwa sebelum menyusun soal, guru perlu mempersiapkan hal-hal sebagai berikut; (1) menganalisis KD, (2) merumuskan kisi-kisi soal, (3) menulis soal berdasarkan level kognitif siswa, (4) mereview dan merevisi draft soal secara kualitatif berdasarkan kaidah baku penulisan soal, dan (5) membuat pedoman/rubrik penskoran. Soal yang mengukur keterampilan berpikir tingkat tinggi (HOTS) harus diberikan stimulus, dapat berupa teks, gambar, grafik, atau tabel yang memuat informasi-informasi berdasarkan pengalaman siswa. Sehingga, dengan menggunakan informasi tersebut, soal-soal HOTS menuntut siswa untuk; (1) mentransfer informasi yang ada di soal dari satu konteks ke konteks yang lain, (2) memproses dan menerapkan informasi yang diperoleh dari soal, (3) melihat keterkaitan antar informasi, (4) menggunakan informasi untuk menyelesaikan masalah, dan (5) mengkaji ide dan informasi secara kritis (Widana et al., 2019). Pengabdi mengungkapkan bahwa guru harus tetap semangat meningkatkan kompetensi mereka dalam menyusun soal HOTS. Kondisi ini tidak hanya terjadi di SMP IT Cendikia Takengon saja. Hasil penelitian menunjukkan bahwa guru dan siswa Indonesia tidak terbiasa mengerjakan soal HOTS meskipun soal-soal HOTS telah lama muncul pada buku ajar/teks Matematika di sekolah (Gradini et al., 2018).

Setelah penyajian materi, kegiatan pengabdian kepada masyarakat ini dilanjutkan dengan praktik penyusunan soal LOTS dan HOTS. Pengabdi membagi guru menjadi kelompok-kelompok sesuai dengan mata pelajaran yang diampu. Kelompok guru lalu diminta untuk menyusun 6 soal tes sesuai level kognitif. Setelah bekerjasama dalam kelompok, perwakilan guru diminta untuk mempresentasikan hasil kerja mereka. Umumnya, guru telah mampu menyusun soal tes dengan baik. Diperlukan pendampingan lebih lanjut agar kualitas soal yang disusun optimal.

Kegiatan selanjutnya adalah pendampingan pada beberapa guru dalam menyusun soal tes untuk Penilaian Akhir Sekolah (PAS). Pada sesi ini dilakukan review dan revisi terhadap kualitas soal yang disusun. Soal PAS yang dirancang umumnya telah memenuhi standar penulisan soal yang baik dan telah mengukur keterampilan berpikir tingkat rendah dan tingkat tinggi siswa.

Setelah mengikuti kegiatan pelatihan, terdapat perubahan persepsi guru dan peningkatan kemampuan dalam merancang tes yang mengukur kemampuan berpikir tingkat rendah dan tingkat tinggi. Pemahaman kepada 
guru tentang perumusan soal tes yang baik dan sesuai standar penilaian juga turut meningkat. Peningkatan kompetensi dan pemahaman guru ini dapat dijabarkan sebagai berikut.

Guru telah mampu menuliskan soal sesuai dengan kaidah penulisan soal, baik soal pilihan ganda maupun uraian. Sebelum mendapatkan pelatihan, mayoritas guru masih mengalami kendala dalam kontruksi soal, terutama soal pilihan ganda, diantaranya; (1) soal belum merepresentasikan seluruh indikator pencapaian kompetensi, (2) Pilihan jawaban belum homogen, (3) masih terdapat informasi yang tidak diperlukan pada pokok soal, dan (4) pokok soal mengandung pernyataan negatif ganda. Gambar 2 menyajikan contoh soal tes dengan pilihan jawaban tidak homogen.

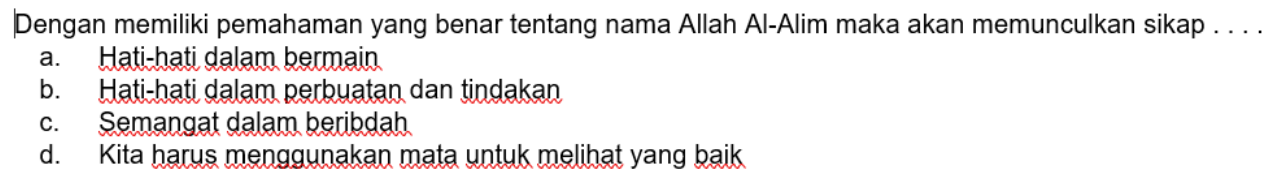

Gambar 2. Contoh soal tes yang disusun sebelum pelatihan

Setelah mendapatkan pelatihan, guru telah menemukan kesalahan dari soal ini, yakni tidak homogennya jawaban yang diberikan dan pokok soal tidak jelas. Guru diminta merevisi soal dengan mengikuti kaidah penulisan soal pilihan ganda yang tercantum di Panduan Penulisan Soal SMP/MTs yang menyatakan bahwa soal harus merepresentasikan seluruh indikator pencapaian kompetensi, pilihan jawaban harus homogen, informasi ada pokok soal diperlukan untuk menjawab soal, dan pokok soal mengandung tidak mengandung pernyataan negatif ganda (Pusat Penilaian Pendidikan, 2017). Perbaikan yang harus dilakukan adalah dengan mencantumkan pilihan jawaban yang homogen dan merevisi pokok soal agar dapat dipahami siswa. Perbaikan yang dilakukan guru disajikan pada gambar 3 .

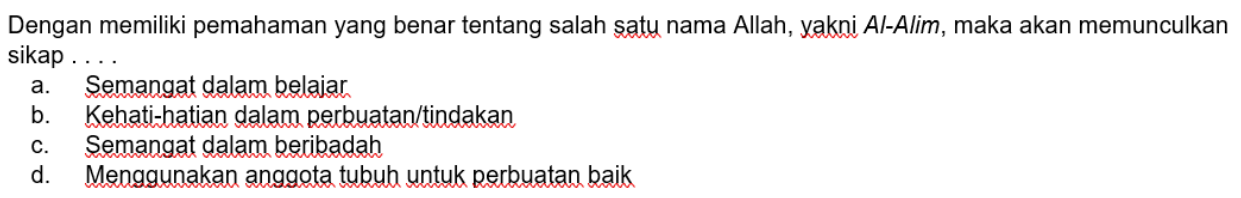

Gambar 3. Contoh soal tes yang diperbaiki setelah pelatihan

Terjadi perubahan pemahaman guru terhadap level kognitif. Pada awalnya, guru salah memahami level kognitif sebagai dimensi kognitif (C1, C2, C3, C4, C5, dan C6). Setelah mendapatkan pelatihan, guru telah memahami bahwa terdapat 3 level kognitif, yakni:

1. Level 1 - Pengetahuan dan Pemahaman. Level ini merupakan level LOTS, mencakup dimensi proses berpikir mengetahui $(C 1)$ dan memahami $(C 2)$. Ciri-ciri soal pada level 1 adalah mengukur pengetahuan faktual, konsep, dan prosedural. 
2. Level 2 - Aplikasi. Level 2 merupakan level LOTS, menunjukkan dimensi proses berpikir menerapkan atau mengaplikasikan (C3). Ciri-ciri soal pada level 2 adalah mengukur kemampuan; a) menggunakan pengetahuan faktual, konseptual, dan prosedural tertentu pada konsep lain dalam mata pelajaran yang sama atau lainnya; atau b) menerapkan pengetahuan faktual, konseptual, dan prosedural tertentu untuk menyelesaikan masalah rutin (Widana et al., 2019).

3. Level 3 - Penalaran. Level ini merupakan level HOTS karena siswa harus mampu mengingat, memahami, dan menerapkan pengetahuan faktual, konseptual, dan procedural serta memiliki logika dan penalaran yang tinggi untuk memecahkan masalah-masalah kontekstual (situasi nyata yang tidak rutin) pada soal ini (Widana et al., 2019). Level penalaran mencakup dimensi proses berpikir menganalisis (C4), mengevaluasi (C5), dan mencipta (C6).

Guru telah mampu memahami dan membedakan soal LOTS dan HOTS. Umumnya guru telah mampu menyusun soal HOTS meski terdapat beberapa guru yang masih kesulitan merancang soal HOTS. Berikut adalah soal LOTS dan HOTS yang dirancang guru SMP IT Cendikia Takengon untuk setiap level kognitif siswa.

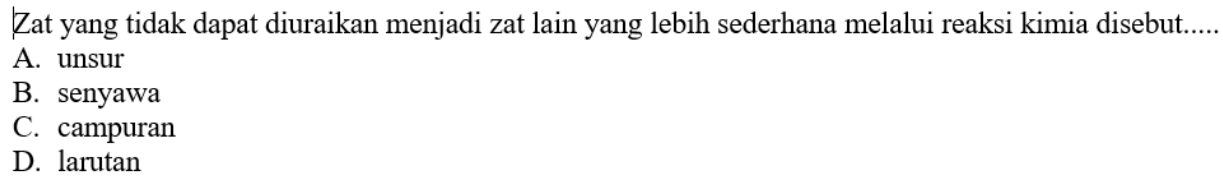

Gambar 4. Soal Level 1 (LOTS) mata pelajaran IPA

Fill the blank with the correct answer! Use the word below! (Thank you) (How are you?) (I am so sorry) (Good Morning) (No problem)

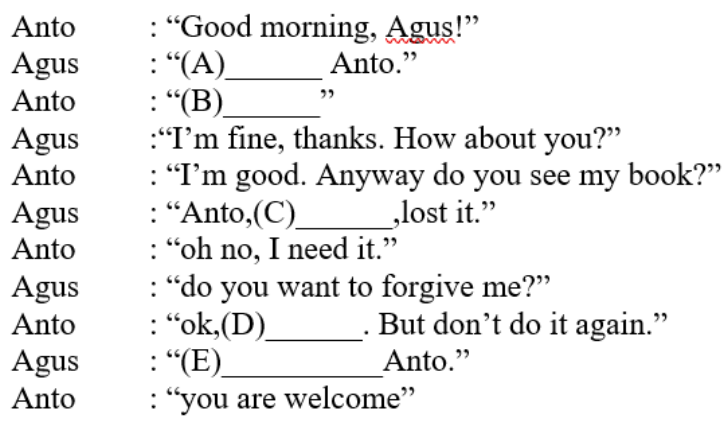

Gambar 5. Soal level 2 (LOTS) mata pelajaran Bahasa Inggris 
Annisa menabung uangnya di Bank Syariah Islami. Setiap bulan besar tabungan bertambah secara tetap dimulai dari bulan pertama Rp50.000,00, bulan kedua Rp55.000,00, bulan ketiga Rp60.000,00, dan seterusnya. Jumlah tabungan selama 10 bulan adalah....
A. $\operatorname{Rp} 550.000,00$
B. $\operatorname{Rp} 600.000,00$
C. $\operatorname{Rp} 700.000,00$
D. Rp $725.000,00$

Gambar 6. Soal level 3 (HOTS) mata pelajaran matematika

Selain peningkatan pemahaman, persepsi guru turut berubah setelah mengikuti pelatihan penyusunan soal bermuatan LOTS dan HOTS. Sebelum mendapatkan materi, $90.32 \%$ guru berpendapat bahwa soal HOTS adalah soal yang sulit dan soal LOTS adalah soal yang mudah. Pandangan ini berubah setelah mengikuti kegiatan, semua guru telah mengetahui bahwa soal HOTS bukanlah soal sulit, melainkan soal level 3 yang melibatkan penalaran (reasoning), dengan dimensi kognitif menganalisis (C4), mengevaluasi (C5), dan mencipta (C6). Namun, pengabdi mengingatkan guru-guru untuk tidak terjebak pada penggunaan Kata Kerja Operasional (KKO) untuk setiap dimensi kogniitf.

Sebelum mendapatkan materi, guru SMP IT Cendikia Takengon juga berasumsi bahwa Non-constructed Response Test berupa soal pilihan ganda tidak dapat mengukur kemampuan berpikir tingkat tinggi (Higher-order Thinking Skills) tetapi hanya dapat mengukur Kemampuan berpikir tingkat rendah (Lower Order Thinking Skills). Mereka berpendapat bahwa soal HOTS haruslah soal uraian (Constructed Response Test). Setelah mengikuti pelatihan, guru memahami bahwa soal tes terstruktur dan tidak terstruktur bila dirancang dengan baik potensial untuk mengukur baik kemampuan berpikir tingkat rendah maupun tingkat tinggi.

\section{KESIMPULAN}

Kegiatan pengabdian kepada masyarakat dalam bentuk pelatihan penyusunan soal bermuatan LOTS dan HOTS pada guru SMP IT Cendikia Takengon berlangsung dengan baik dan mencapai tujuan pelaksanaan kegiatan. Pelatihan ini berhasil meningkatkan kompetensi guru dalam merancang tes yang mengukur kemampuan berpikir tingkat rendah dan tingkat tinggi. Pelatihan ini juga berhasil memberikan pemahaman kepada guru tentang perumusan soal tes yang baik dan sesuai standar penilaian yang diatur oleh Kementerian Pendidikan dan Kebudayaan. Berdasarkan hasil evaluasi dan refleksi, diperoleh bahwa; (1) guru-guru telah mampu menuliskan soal sesuai dengan kaidah penulisan soal, baik soal pilihan ganda maupun uraian; (2) guruguru telah mampu memahami dan membedakan antara level kognitif (Level 1,2, dan 3) dan dimensi kognitif (C1, C2, C3, C4, C5, dan C6); (3) guru-guru telah mampu memahami dan membedakan soal LOTS dan HOTS; (4) umumnya guru telah mampu menyusun soal HOTS meski terdapat beberapa guru yang masih kesulitan merancang soal HOTS; (5) guru telah mengetahui bahwa soal 
HOTS bukanlah soal sulit, melainkan soal level 3 yang melibatkan penalaran (reasoning); dan (6) guru-guru memahami bahwa soal tes terstruktur dan tidak terstruktur bila dirancang dengan baik potensial untuk mengukur baik kemampuan berpikir tingkat rendah maupun tingkat tinggi.

Kegiatan pengabdian kepada masyarakat ini masih perlu mendapatkan perbaikan, terutama dari segi teknisnya. Pada proses pendampingan, tidak semua guru mendapatkan sesi bimbingan lanjut dari pengabdi. Hal ini dikarenakan keterbatasan tenaga pengabdi dan dapat disiasati kedepannya dengan membentuk tim pengabdian dengan jumlah anggota yang lebih banyak dan mewakili semua mata pelajaran di sekolah dampingan.

\section{DAFTAR RUJUKAN}

Anderson, L. ., Krathwohl, D. ., Airasian, P. ., Cruikshank, K. ., Mayer, R. ., Pintrich, P. ., Raths, J. ., \& Wittrock, M. . (2001). A Taxonomy for Learning, Teaching, and Assessing: A Revision of Bloom's Taxonomy of Educational Objectives. In Longman.

Bloom, B. S., Engelheart, M. D., Furst, E. J., Walker H, H., \& Krathwohl, D. . (1956). Taxonomy of Educational Objectives: The Classification of Educational Goals. Handbook 1. Cognitive Domain. In Longman, Green and Co Ltd (1st ed.). https://doi.org/10.1300/J104v03n01_03

Dewi, T. U., \& Handayani, S. L. (2020). Pelatihan Pembuatan Soal Berbasis Digital Bagi Guru SMA di Era Revolusi Industri 4.0. Jurnal Inovasi Hasil Pengabdian Masyarakat (JIPEMAS), 3(2), 146-153. https://doi.org/10.33474/jipemas.v3i2.6697

Gradini, E. (2019). Menilik Konsep Kemampuan Berpikir Tingkat Tinggi (Higher Order Thingking Skills) dalam Pembelajaran Matematika. Jurnal Numecary, 6(2), 189-203. https://doi.org/10.46244/numeracy.v6i2.475

Gradini, E., Firmansyah B, \& Noviani, J. (2018). Menakar Kemampuan Berpikir Tingkat Tinggi Calon Guru Matematika Melalui Level HOTS Marzano. Eduma: Mathematics Teaching and Learning, 7(2), 41-48. https://syekhnurjati.ac.id/jurnal/index.php/eduma/article/view/3357

Hidayati, A. U. (2017). Melatih Keterampilan Berfikir Tingkat Tinggi Dalam Pembelajran Matematika Pada Siswa Sekolah Dasar. TERAMPIL Pendidikan Dan Pebelajaran Dasar, 4(20), 143-156. https://doi.org/10.24042/terampil.v4i2.2222

Lestari, A., Saepulrohman, A., \& Hamdu, G. (2016). Pengembangan Soal Tes Berbasis HOTS Pada Model Pembelajaran Latihan Penelitian Di Sekolah Dasar. PEDADIDAKTIKA: Jurnal IImiah Pendidikan Guru Sekolah Dasar, 3(1), 74-83. https://ejournal.upi.edu/index.php/pedadidaktika/article/view/4801

Lewis, A., Smith, D., \& Lewis, A. (2009). Defining Higher Order Thinking. Theory Into Practice, 32(March 2015), 131-137. https://doi.org/10.1080/00405849309543588

McMillan, J. H., Venable, J. C., \& Varier, D. (2013). Studies of the effect of formative assessment on student achievement: So much more is needed. Practical Assessment, Research and Evaluation, 18(2), 1-15. 
https://doi.org/10.7275/tmwm-7792

Miarsyah, M., \& Ristanto, R. H. (2019). Memberdayakan Keterampilan Mengembangkan Soal Hots pada Guru Biologi di Kabupaten Bekasi. BAKTIMAS: Jurnal Pengabdian Pada Masyarakat, 1(4), 151-159. https://doi.org/10.32672/btm.v1i4.1718

Newmann, F. M. (1991). Classroom Thoughtfulness and Students' Higher Order Thinking: Common Indicators and Diverse Social Studies Courses. Theory and Research in Social Education, 19(4), 410-433. https://doi.org/10.1080/00933104.1991.10505649

Phelps, R. P. (2012). The Effect of Testing on Student Achievement, 19102010. International Journal of Testing, 12(1), 21-43. https://doi.org/10.1080/15305058.2011.602920

Popham, W. J. (2003). Test better, teach better: the instructional role of assessment. In ASCD (Vol. 42, Issue 01). https://doi.org/10.5860/choice.42-0445

Pusat Penilaian Pendidikan. (2017). Pedoman Penulisan Soal SMP/MTs (K. P. dan K. Pusat Penilaian Pendidikan, Badan Penelitian dan Pengembangan (ed.)).

Stanley, T., \& Moore, B. (2013). Critical Thinking and Formative Assessments. In Critical Thinking and Formative Assessments. https://doi.org/10.4324/9781315856261

Suyitno, A. (2013). Mengembangkan Kemampuan Guru Matematika Dalam Menyusun Soal Bermuatan Literasi Matematika Sebagai Wujud Implementasi Kurikulum 2013. AKSIOMA Jurnal Matematika Dan Pendidikan Matematika, https://doi.org/10.26877/aks.v4i2/Septembe.552

$4(2)$.

Wicaksono, A. G., \& Jumanto, J. (2019). Pengembangan Soal Higher Order Thinking Skills (Hots) Bagi Guru Sekolah Dasar. Adi Widya: Jurnal Pengabdian Masyarakat, 3(2), 14-20. https://doi.org/10.33061/awpm.v3i2.3352

Widana, I. wayan, Adi, S., Herdiyanto, Abdi, J., Marsito, \& Istiqomah. (2019). Modul Penyusunan Soal HOTS Matematika. Direktorat Pembinaan Sekolah Menengah Atas.

Wiliam, D., Lee, C., Harrison, C., \& Black, P. (2004). Teachers developing assessment for learning: Impact on student achievement. Assessment in Education: Principles, Policy and Practice, 11(1), 49-65. https://doi.org/10.1080/0969594042000208994

Wilson, L. O. (2016). Anderson and Krathwohl Bloom's Taxonomy Revised: Understanding the New Version of Bloom's Taxonomy. In The Second Principle (pp. 1-8). 